\title{
土木工程施工技术要点与现场控制
}

黄羽

广西建工集团联合建设有限公司

DOI:10.18686/bd.v2i8.1547

[摘 要] 本文主要针对土木工程施工技术, 以及现场控制要点展开详细的分析和研究, 希望可以有效的提升土木工程施工 质量,为我国土木工程的发展贡献力量。

[关键词] 土木工程;施工技术;现场控制

市场经济的发展，使得各行各业的竞争形式越来越严 重, 建筑企业为了在激烈的市场竞争中发挥自身的优势,首 先就需要对施工质量进行控制。所以在土木工程施工时,要 明确技术使用重点, 加强问题的处理效率, 进而保证建设的 质量。

\section{1 土木工程施工技术发展情况}

1.1 施工团队综合素质较低

土木工程施工中,要想提高技术使用的效果,首先要对 技术操作人员实行相应的规范要求, 只有这样才能保证各 项目施工质量的标准性。所以在实际的施工作业中, 要让施 工人员明确操作标准, 并按照具体的操作要求进行施工作 业, 严格控制技术使用过程, 为施工质量的提升提供条件。不 过我国现阶段土木工程建设中, 其施工人员以农民居多, 这 些人员由于未经过专业的培训, 且对于新技术以及工艺的 学习能力也较差,导致施工技术的控制存在一定的困难性。 这就需要企业加强岗前培训力度, 制定合理的培训内容以 及考核标准,从整体上提高员工的专业水平。

\section{2 材料质量不合格}

土建施工中, 如果出现施工材料质量不合格的情况,其 不仅会影响材料使用的效率, 降低工程质量,还会在一定程 度上增加成本的支出,降低企业的经济效益。但是很多的施 工企业却并未意识到这点, 为了创造更多的经济效益, 很多 的企业在材料采购时, 不断的降低采购经费, 或者直接选购 一些价格较为便宜的材料应用到施工中。另外还有些企业 出现偷工减料、以次充好的情况, 从而影响了整个工作的效 果,这也为工程埋下了安全隐患。所以,有关部门应加强材料 的管理, 运用科学合理的方式对材料质量进行检查和验收, 确保材料性能的合理发挥, 为土木工程施工质量的提升奠 定基础。

1.3 施工条件的制约

由于土建施工大多都是室外作业, 这使得其在施工中 很容易受到施工条件以及环境等因素的制约。再加上土建 工程规模较大,施工周期较短, 部分施工单位会在晚间开始 工作, 在光照以及疲劳等因素的影响下, 很容易导致施工质 量出现问题。因此, 在土建施工中, 有必要结合现场的具体情 况合理的选择施工技术, 并对施工流程实行明确规划, 同时
细致的考察周边环境,并完善施工方案的内容, 以此增大施 工的可行性。如果一定要夜间操作,也要保证照明等设施使 用的合理性,保证安全施工。

\section{2 土建施工的技术要点}

2.1 深基坑施工

深基坑施工技术虽然看似简单, 但是其对结构的稳固 以及周边环境有着重要的影响,一旦其出现问题,将会降低 整个土建施工的效果。所以在具体的操作中,需明确深基坑 技术的重点内容,对其进行详细的研究和控制。同时在使用 深基坑技术前,还要对技术人员进行严格的规范,保证操作 的标准性。另外在施工前,施工现场的勘察同样关键,且要掌 握区域内的地质、水文、环境等特征, 做好相应的防范工作, 降低深基坑操作的危险性。

\section{2 混凝土施工}

首先要对混凝土模板的质量进行验收, 在确保其质量 合格后,方可展开浇筑作业。

其次,在混凝土调配时,要准确的计算原材料用量以及 拌合时间, 以确保混凝土材料质量的合理性, 使混凝土材料 性能得到充分发挥。

再次, 在梁板浇筑工作开始前, 不仅要对钢筋混凝土结 构的稳定性展开详细的检查, 还要严格的控制振捣作业, 保 证振捣的频率和次数, 减少漏振等情况的发生。在振捣完成 后, 即可开始混凝土的浇筑施工。在浇筑环节内, 要保证浇筑 作业的连续性, 如果是利用分层方式进行浇筑作业, 一定要 在一层初凝后再开始二层的浇筑工作, 并注意把控浇筑的 时间。

最后, 混凝土结构的养护。通常所使用的养护方式有浇 水和覆盖这两种,养护的时间大多在一周到半个月左右。且 在养护环节内, 一旦发现裂缝的产生, 要及时的采取处理措 施, 以免影响结构的性能,降低后期使用的效率。

\section{3 钢筋施工}

钢筋对于提升结构的稳固性以及承载能力有着重要的 作用。所以在土建施工中, 对于钢筋材料的使用数量、规格 等一定要进行合理的控制, 以保证结构的整体稳定效果。另 外在钢筋施工中, 要严格选择和把控施工工艺, 只有这样才 能更好的完善钢筋的性能。加之, 在钢筋材料进场后, 应将其 
放在较为干燥的区域进行保存, 以免因为潮湿导致钢筋出 现氧化、腐蚀等现象,影响钢筋的质量。在绑扎作业时,按照 图纸设计的内容实行操作,且要设置相应的保护层, 提高绑 扎工作的质量。

2.4 排水施工

夏季我国的雨量相对较多,特别是在沿海城市内,很容 易因为降水而导致洪涝灾害的发生, 所以排水工程建设的 质量对于土建施工有着关键的作用。(1)施工部门要结合工 程的情况组织排水施工作业。(2)制定科学合理的管理制度, 优化排水施工。(3)加强各部门之间的沟通和协作能力, 通过 先进技术以及理念的应用来提升排水系统的运行效率, 实 现水资源的合理利用。

\section{5 模板施工}

模板施工前, 要先制定明确的安装计划以及施工方案, 在经领导部门批准后,方可开始施工操作。之后注意技术交 底工作, 确保安装人员明确模板施工中技术的使用以及工 程标准情况。在土建施工中,大多都是采用双层胶合板的方 式进行的, 故而需要严格的控制模板之间的距离以及纵向 杆剪力结构。然后利用合理的测量方式检测模板的垂直角 度,这样可以加大脚手架和模板之间的连接性, 保证安装工 作的安全,最后利用螺丝对其实行固定,提高模板的稳定性。

\section{3 土建施工现场管理的措施}

3.1 现场人员管控

在管理工作开展的过程中，应有效的划分现场工作人 员的责任,提升工作人员对管理工作的重视程度,激发其对 管理工作的参与热情,从而保证管理工作的顺利开展。同时 还要制定合理的奖惩制度,做到奖罚分明。再者,建立完善的 管理制度, 并落实到具体的施工作业中, 以此加强管理的有 效性。

\section{2 材料质量管控}

在土建施工中, 加强施工材料质量管控力度和效果, 是 提高施工质量的前提和基础。

首先,施工部门要同材料生产商进行有效的沟通, 确定 材料的种类、规格、数量,并检测材料的质量, 在保证其质量 合格后,签订相应的供货合同,以确保材料使用与施工需求 相符。

其次,在施工建材采购过程中,任何施工单位立足于市 场的根本目的都是盈利, 这是各企业单位发展的要义, 而且 施工单位在建材采购时也务必要注意成本的控制。同样的, 注意与生产厂家的交流,必要时还要进行观察和询问,既要 询问价格,又要观察建材质量。或者也可控制建材成本, 这样 能够扩大单位利润空间, 在比对和分析各材料厂家后货比 三家,择优选用。
最后,应及时的验收和存管进场的施工材料,一旦发现 存在质量问题需及时对其更换, 以免影响施工作业的进行。 同时按照材料的性能以及使用顺序对其实行合理的摆放, 该操作可节省施工的时间,提升施工效率。在全面了解施工 情况以后,方可有效安排建材进场工作,管理者要严格验收 进场材料, 且将结果向设计单位上报, 至于建材人场的数量, 则需结合施工进度而定, 以免进场材料太多而挤占场地。

\section{3 施工技术管控}

施工技术的应用情况会对工程建设的质量、安全带来 相应的影响,所以在进行现场施工管理时, 要加强施工技术 的管控力度,有针对性的采取技术控制措施。在土木工程施 工过程中,交叉施工作业环节非常的多,管理人员应当做好 施工技术配合与协调工作。为了能够对工程项目造价加强 控制,需管控施工技术成本，以免出现因技术应用及管理乏 力而出现造价超标等系列问题。另外, 还要优化现场施工环 境,将影响施工安全的隐患进行及时的清楚和解决, 确保土 建施工的顺利开展。

\section{4 施工进度管控}

施工进度的控制不仅仅是为了保证施工质量, 增加企 业的经济效益,还可以增加企业的信誉,帮助企业树立良好 的形象。在土建施工前,工作人员需制定合理的进度计划书, 按照合同的内容及时开展工程交付作业。之后结合进度目 标的情况合理的进行施工内容以及时间的划分, 以免出现 工期延误现象。此外,对于因进度产生的纠纷和矛盾,双方应 在初期就做好明确的规定，然后采用先进的科技技术控制 好施工进度。在土木工程施工进度的控制过程中, 建议利用 现代信息技术手段实施监控, 以此来保证各分项工程项目 的施工质量。

\section{4 结束语}

结合上述所说,随着工程建设数量的增多, 建筑施工安 全问题成为当前工程项目的重点内容, 在施工现场管理时, 要将施工质量以及安全作为重点关注的核心内容, 这就要 求管理人员需针对不同施工环节的要求, 选择合理的施工 技术,制定合理的技术操作标准, 以此提高技术使用的规范 性, 从根本上杜绝危险问题的发生, 最终为企业效益的增长 提供支持。

\section{参考文献：}

[1]何晓晶.浅谈土木工程管理的重要性及发展趋势[J]. 中国住宅设施,2017(09):104-105.

[2]李怡坤.土木工程建筑中混凝土结构的施工技术探 讨[J].工程技术研究,2017 (10):78-79.

[3]周毅恒.土木工程的建筑质量控制研究 [J].农家参 谋,2018(07):197. 